\title{
HOW THE FREQUENCY OF PAIN IN THE EARLY STAGES OF PARKINSON'S DISEASE AFFECTS THE SPEED OF DIAGNOSIS
}

\author{
PARKINSON HASTALIĞI BAŞLANGICINDA GÖRÜLEN AĞRI SIKLIĞI VE TANI SÜRESINE \\ ETKISI
}

\author{
Bedia SAMANCl${ }^{1}$ D , Nazlı DURMAZ ÇELIK² (D), Başar BiLGiÇ ${ }^{1}$, Serhat ÖZKAN² (D), Haşmet Ayhan HANAĞASI ${ }^{1}$ \\ ${ }^{1}$ Istanbul University, Istanbul Faculty of Medicine, Department of Neurology, Behavioral Neurology and Movement Disorders Unit, \\ Istanbul, Turkey \\ ${ }^{2}$ Eskisehir Osmangazi University, School of Medicine, Department of Neurology, Eskisehir, Turkey
}

ORCID IDs of the authors: B.S. 0000-0003-0667-2329; N.D.Ç. 0000-0002-2943-2240; B.B. 0000-0001-6032-0856; S.Ö. 0000-0002-5874-5270; H.A.H. 0000-0002-4624-4428

Cite this article as: Samanci B, Durmaz Celik N, Bilgic B, Ozkan S, Hanagasi HA. How the frequency of pain in the early stages of Parkinson's disease affects the speed of diagnosis. J Ist Faculty Med. Published online February 3, 2022. doi: 10.26650/IUITFD.1019934

\section{ABSTRACT}

Objective: The fact that non-motor symptoms such as pain in Parkinson's disease (PD) are more associated with musculoskeletal diseases (MSD) suggests that there may be delays in diagnosis. The aim of this study was to review the first symptoms of PD, especially pain, while at the same time reviewing the medical specialists to whom patients first went and examining the effects of these parameters on time to diagnosis and treatment.

Materials and Methods: Patients with PD were included. The patients were evaluated in terms of clinical features, initial complaints and onset time, presence and type of pain, the medical specialist they first applied to, and time to diagnosis.

Results: Eighty-six patients were included ( 42 female, 44 male). The first complaints were bradykinesia, tremor, tremor and bradykinesia, shoulder pain, tremor and painful cramps. These complaints started $10.1 \pm 5.22$ years previously, and the diagnosis of PD was made $8.56 \pm 4.87$ years previously on average. The first specialist departments to which patients with these complaints applied were Neurology $(n=34)$, Physical Therapy and Rehabilitation $(n=34)$, Neurosurgery $(n=10)$, and Orthopedics $(n=8)$. The first admission to Neurology was $8.7 \pm 4.85$ years previously. Pain complaints started $7.2 \pm 6.69$ years before the first admission in 56 patients. Musculoskeletal pain was $86 \%$, dystonic pain was $25 \%$, central pain and neuropathic pain were $11 \%$ each in the group of patients who had experienced pain.

Conclusion: PD can be confused with MSD due to findings such as pain and rigidity, which may cause a delay in diagnosis and treatment. This delay can be prevented if non-neurology

\section{ÖZET}

Amaç: Parkinson hastalığında (PH) ağrı gibi non-motor bulguların kas-iskelet sistemi hastalıkları ile daha çok ilişkilendirilmesi tanıda gecikmeler yaşanabileceğini düşündürmektedir. Bu çalışmada PH'de ağrı başta olmak üzere ilk semptomların ve başvurulan branşların gözden geçirilmesi ve bu başvuruların tanı ve tedavi süresine etkisini incelemek amaçlanmıştır.

Gereç ve Yöntem: Çalışmaya PH tanılı hastalar dahil edildi. Hastalar klinik özellikleri, ilk yakınmaları ve yakınma başlangıç zamanı, ağı yakınmasının varlığı ve tipi, ilk başvurdukları branş ve tanı süreleri yönünden değerlendirildi.

Bulgular: Çalışmaya 86 hasta dahil edildi (42'si kadın, 44'ü erkek). ilk yakınma hareketlerde yavaşlık, tremor, tremor ve hareketlerde yavaşlık, omuz ağrısı, tremor ve ağrılı kasılma idi. Hastaların ilk yakınmaları 10,1 $\pm 5,22$ yı önce başlamıştı, $\mathrm{PH}$ tanısı ise ortalama $8,56 \pm 4,87$ yı önce konmuştu. Yakınmaları nedeniyle ilk başvurulan branş 34 hastada Nöroloji, 34 hastada Fizik Tedavi ve Rehabilitasyon, 10 hastada Beyin ve Sinir Cerrahisi, 8 hastada Ortopedi

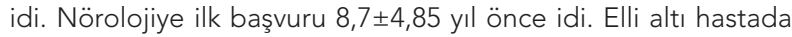
ilk başvurudan 7,2 6,69 yıl önce ağrı yakınması başlamıştı. Ağrıı hasta grubunda kas-iskelet ağrısı \%86, distonik ağrı \%25, santral ağrı ve nöropatik ağrının her biri \%11 oranındaydı.

Sonuç: Parkinson hastalığı ağı ve katılık gibi bulgular nedeniyle kas-iskelet sistemi hastalıkları ile karışabilmekte, bu durum tanı ve tedavi süresinin gecikmesine neden olabilmektedir. Nöroloji dışı branşlara hastalık hakkında daha detaylı eğitim verilmesi, halkın hastalık bulguları konusunda bilinçlenmesi bu gecikmenin önüne geçebilir.

Corresponding author/Iletişim kurulacak yazar: bediasamanci@gmail.com

Submitted/Başvuru: 06.11.2021 • Revision Requested/Revizyon Talebi: 24.11.2021 •

Last Revision Received/Son Revizyon: 24.11.2021 • Accepted/Kabul: 29.11.2021 • Published Online/Online Yayın: 03.02.2022 
specialists are provided with more detailed training about the disease, and if public awareness is raised about the signs and symptoms of PD.

Keywords: Parkinson's disease, pain, non-motor symptoms, musculoskeletal symptoms
Anahtar Kelimeler: Parkinson hastalığı, ağrı, non-motor semptomlar, kas-iskelet semptomları

\section{INTRODUCTION}

Parkinson's disease (PD) is a progressive disease and of all neurodegenerative diseases it is the second most common. Non-motor symptoms such as sleep disorders, pain, autonomic findings, anosmia, depression, anxiety, apathy, and cognitive impairment can be observed much before motor symptoms (1-3). Early diagnosis and treatment increase the quality of life $(\mathrm{Q} \circ \mathrm{L})$ and reduce the burden of caregivers $(4,5)$.

Population-based studies show that a significant proportion of patients diagnosed with PD are diagnosed late (6). Clinicopathological studies have shown that erroneous diagnoses can be made even in patients examined by a movement disorders specialist (7). Therefore, it is essential to recognize the non-motor symptoms as well as the motor symptoms of the disease. The prevalence of pain in PD is between 40-85\%, and pain typically appears in five categories as musculoskeletal pain, dystonic pain, central/primary pain, radicular/neuropathic pain, and akathisia (8). The fact that the complaint of pain is sometimes seen before the motor findings or in the very early stages of the disease may cause diagnostic difficulties in this patient group. Another condition that causes a delay in diagnosis is the tendency of patients to apply to medical specialties other than neurology for these complaints. The most important determinants of early diagnosis and access to treatment are factors such as the occurrence of the disease in the younger patient group where it is seen more rarely, the presence of early non-motor/obscure motor findings, and knowledge of which physician the patient was first examined by in regard to PD.

The aim of this study was to review the first symptoms of $P D$, especially pain, while at the same time reviewing the medical specialists by whom the patients were examined and analysing the effects of these parameters on time to diagnosis and treatment.

\section{MATERIAL AND METHOD}

\section{Patient selection and data collection}

Patients diagnosed with PD according to the diagnostic criteria provided by the Movement Disorders Society (MDS) and who were followed up in the Movement Disorders outpatient clinics of the Neurology Department of two tertiary care centers were included in the study. Patients with parkinsonism due to secondary causes were excluded (9). The files of 86 patients with PD who had applied to the Movement Disorders outpatient clinic in the previous three months were reviewed retrospectively. The patients were evaluated based on their clinical and demographic characteristics, non-motor findings, initial complaints, onset date, pain complaints and type of pain, the medical specialty they first applied to, and time to diagnosis and treatment. Pain type was divided into five categories, namely musculoskeletal pain, dystonic pain, central/primary pain, radicular/neuropathic pain, and akathisia (8). Depending on its location the pain was categorized as either shoulder pain, low back pain, or cramp-like pain in the extremities. Informed consent was obtained from the patients. Ethics committee approval of the study was obtained from the Istanbul Faculty of Medicine Ethics Committee (Date: 22.02.2021, No: 94690).

\section{Statistical analysis}

In order to evaluate the demographic and clinical characteristics of the study cohort, independent sample t-test was used for continuous variables, and chi-square test was used for categorical variables. Categorical variables were presented as numbers and percentages, and continuous variables as mean and standard deviation. Data analysis was performed using the SPSS 23.0 (IBM Corp., Armonk, NY, USA).

\section{RESULTS}

Of the 86 patients included in the study, 42 were female, and 44 were male. The mean age of the patients was $61.4 \pm 9.94$ years. The first complaint was bradykinesia in 36 patients, tremor in 24 patients, tremor and bradykinesia in 8 patients, shoulder pain in 16 patients, tremor and painful cramps in 2 patients. The first complaints of the patients started $10.1 \pm 5.22$ years previously, and the diagnosis of PD was made $8.56 \pm 4.87$ years earlier on average. The first specialty to which patients with these complaints applied was Neurology in 34 patients, Physical Therapy and Rehabilitation in 34 patients, Neurosurgery in 10 patients, and Orthopedics in 8 patients (Figure 1). The first admission to Neurology was $8.7 \pm 4.85$ years previously. Of the patients whose first admission was a non-neurology specialty, 38 (73\%) of them were admitted to the Neurology outpatient clinic on their own because of worsened complaints, and 14 (27\%) of them were referred to the Neurology outpatient clinic by another physician. 


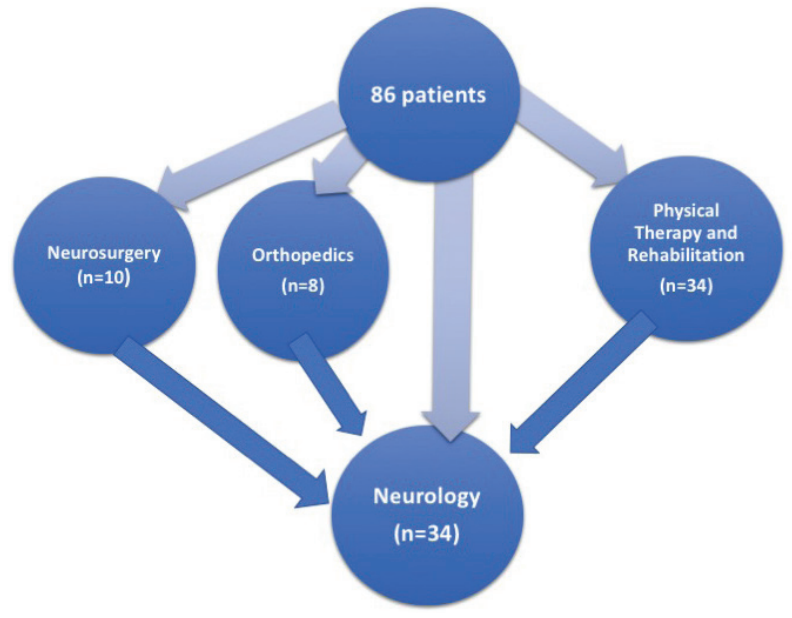

Figure 1: The medical specialties to which the patients applied. The first applied specialties are shown with light blue arrows and the second with dark blue arrows (The number of initially applied patients is given in parentheses).

All patients had at least one non-motor symptom other than pain, and these findings started a mean of $4.2 \pm 4.23$ years before the onset of their symptoms (Table 1).

Pain complaints started $7.2 \pm 6.69$ years before the first admission in 56 patients $(65.1 \%)$. Thirty (54\%) of the patients with pain complaints were female, 26 were male (46\%), and the mean age was $60.6 \pm 10.44$ years. Although more than one type of pain could be seen in the same person, the predominant pain was shoulder pain in 34 patients, low-back pain and rigidity in 14 patients, and cramp-like pain in the upper and lower extremities in eight patients. All of the patients had received medical treatment and physiotherapy for these reasons. Twenty-two (65\%) of the patients with shoulder pain, 4 (29\%) of the patients with low back pain, and 4 (50\%) of the patients with cramp-like pain were male. In 13 (38\%) patients with shoulder pain, the pain was ipsilateral to where parkinsonism was dominant, and it was contralateral in four (12\%). The remain-
Table 1: Non-motor findings seen in patients

\begin{tabular}{lcc}
\hline & $\begin{array}{c}\text { Number } \\
\text { of patients } \\
\text { ( } \mathbf{n}=\mathbf{8 6})\end{array}$ & $\%$ \\
Pain & 56 & 65.1 \\
Constipation & 54 & 62.8 \\
RSBD* & 37 & 43 \\
Hyposmia/anosmia & 21 & 24.4 \\
Urinary problem** & 18 & 21 \\
Daytime sleepiness/sleep disorder & 15 & 17.4 \\
Mood change/apathy & 3 & 3.5 \\
Orthostasis & 2 & 2.3 \\
Mild cognitive impairment & 2 & 2.3 \\
\hline *: REM sleep behavior disorder, **: Urinary incontinence (urgency)/ \\
nocturia
\end{tabular}

ing patients could not fully express the side of the pain. When the pain type was divided into musculoskeletal pain, dystonic pain, radicular/neuropathic pain, central pain, and akathisia, it was seen that there could be more than one pain type in the same patient. Regarding pain types, $48(56 \%)$ had musculoskeletal pain, $14(16 \%)$ had dystonic pain, $6(7 \%)$ had central pain, and $6(7 \%)$ had neuropathic pain. Considering the distribution in the group of patients who had pain, musculoskeletal pain was $86 \%$, dystonic pain was $25 \%$, central pain and neuropathic pain were $11 \%$ each (Figure 2). In our patient group, akathisia was not described. The mean age of the patients with dystonic pain was significantly younger than that of the other patients $(50.1 \pm 6.22$ vs. $63.9 \pm 8.79, p<0.001)$.

Fifty-eight patients (67\%) had akinetic-rigid and 28 patients (33\%) had tremor-dominant PD. Twenty-two (38\%) of the akinetic-rigid patients and 12 (43\%) of the tremor-dominant patients initially applied to neurology. While the time between the first visit to a specialist and the

Total number of patients $=86$, Number of patients with pain $=56$

- All patients $=$ Patients with pain

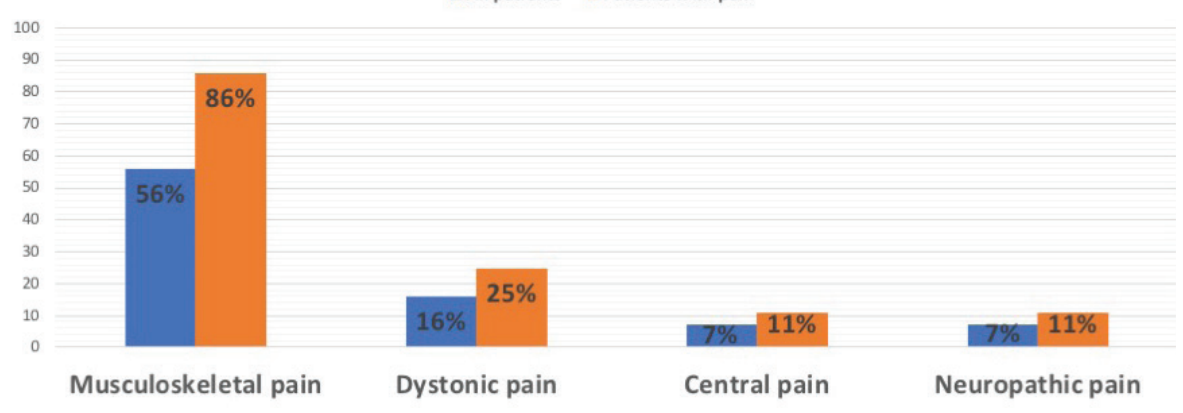

Figure 2: Distribution of pain types in all patients and patient group with pain 
first neurology admission in akinetic-rigid patients was $1.6 \pm 1.01$ years, it was $0.8 \pm 0.79$ in tremor dominant patients $(p<0.001)$. The mean levodopa equivalent dose used was $1204 \pm 448 \mathrm{mg}$. In all patients, the complaint of pain regressed with oral antiparkinsonian therapy. When we questioned our patients retrospectively, 21 patients (37.5\%) with pain stated that the pain had been more restrictive than other complaints in the pre-diagnosis period of the disease.

\section{DISCUSSION}

Pain, like other non-motor findings, can frequently be encountered before motor complaints in PD, both at the onset and during the course of the disease, and this has a serious impact on correct diagnosis, time of access to treatment, and QoL of patients. This study shows that patients tend to associate the pain they experience before or in the early period of their illness with motor complaints and that this leads them to apply to non-neurology specialties. The study also shows that physicians from non-neurology specialties are not familiar with the non-motor symptoms of PD, leading to a delay in diagnosis.

According to current diagnostic criteria, PD is clinically diagnosed mainly when motor findings appear, but there is a prodromal phase in which non-motor findings begin to appear, ranging from 5 to 20 years before diagnosis (10-12). It is essential to question prodromal findings such as REM sleep behavior disorder, cognitive disorder, olfactory disorder, incontinence, constipation, prolonged daytime sleepiness, depression and anxiety, erectile dysfunction, and orthostatic hypotension in suspected patients, and to conduct diagnostic investigations in necessary patients in order to make a correct diagnosis in the early period. According to the MDS criteria for prodromal PD, a Unified Parkinson's Disease Rating Scale (UPDRS) score $>3$ excluding action tremor or an MDS-UPDRS score $>6$ excluding action and postural tremor is a clinical motor marker for prodromal PD, and it indicates that the diagnosis can be made in a period when motor findings are not excessive (12). In one study, 109 newly diagnosed and untreated PD patients and 107 controls were surveyed, and unexplained pain in various parts of the body that started 2-10 years before the onset of motor symptoms was reported in PD patients (13). In another study, which included 436 PD patients, it was reported that $21 \%$ of the patients had prodromal non-motor symptoms and that the most common symptom was pain (14). This suggests that disease progression may be caudo-rostral and that locus ceruleus and raphe nucleus involvement is associated with premotor pain before involvement of the substantia nigra associated with motor findings (15). In addition to being an early symptom and a prodromal symptom, it has been reported that pain is also common in the later stages of the disease (16). In our patient group, pain was the most common complaint (65.1\%) among the non-motor symptoms that started before admission, and it started $7.2 \pm 6.69$ years before the first admission, similar to the literature (12).

Studies have shown that pain as a premotor symptom is seen with a frequency of 30-95\% in patients with PD (1719). Depending on the severity, the first or predominant complaint of the patients may be musculoskeletal pain, and it may occur in association with parkinsonism, that is, with motor complaints such as rigidity and akinesia (20, 21). In the entity that is accepted as central parkinsonian pain, there are criteria such as the onset of pain before the disease, being ipsilateral to where parkinsonism is prominent, and the absence of any other reasons for the pain. Its estimated prevalence has been reported as 4.5$22 \%(17,19,22,23)$. In one study, musculoskeletal pain was found to be $70 \%$, followed by dystonic pain (40\%), radicular-neuropathic pain (20\%), and central pain (10\%) (24). In another study, musculoskeletal pain was found to be $41 \%$, followed by radicular-neuropathic pain (27\%), central pain (22\%), and dystonic pain (17\%) (19). As can be seen, the most common pain subtype is musculoskeletal pain, and it was reported in a recent review that shoulder, low back, neck, knee, and hip pain were prominent $(19,24-26)$. In a study conducted on 198 patients with PD by Bonenfant et al., body pain was found to be $74.2 \%$ regardless of its type and distribution. In addition, studies have reported that $30-71 \%$ of patients complain of more than one type of pain $(19,24,27,28)$. In a study conducted in Turkey the most common type of pain was musculoskeletal pain (44.4\%), followed by dystonic pain (19.1\%) (29). In our patient group, the high number of patients presenting with primary complaints of pain was remarkable $(n=56,65.1 \%)$. Similar to the literature, the most common pain type was musculoskeletal pain, and the second most common was dystonic pain.

In a study conducted by Kim et al. on 400 PD patients and 138 age- and sex-matched controls, there was no significant difference in musculoskeletal problems limiting the activities of daily living (ADL) for both groups (30). However, they reported that $31.8 \%$ of PD patients had more restricted ADLs due to musculoskeletal problems than parkinsonism symptoms. In our patient group, $37.5 \%$ of patients with pain also stated that the pain was more restrictive than that of other complaints. In the same study, it was reported that musculoskeletal complaints were more common in women and elderly patients in the PD group, similar to the normal population. In our study, while the complaint of pain was more common in women (54\%), there was no significant age difference between the group of patients which had experienced pain and the group that had not, unlike what was reported in the literature. Previous studies found that the laterality of the 
complaints and parkinsonism were same in $30 \%$ of PD patients with musculoskeletal problems, different in $9 \%$, and partially the same in the remaining (30). One study found that shoulder pain may occur as the first clinical manifestation, especially in cases of akinesia (31). Consistent with these findings, in our patient group, the number of patients with ipsilateral shoulder pain and parkinsonism was higher than those with contralateral shoulder pain and parkinsonism (38\% vs. $12 \%$ ). It is thought that parkinsonism and ipsilateral pain make the diagnosis difficult, and this finding is notable as the first clinical manifestation.

One of the most common problems experienced by PD patients is pain caused by a frozen shoulder which may occur as a sign of the disease. In a previous study, shoulder complaints (43\% vs. $23 \%$ ) and history of frozen shoulder $(12.7 \%$ vs. $1.7 \%)$ were found to be considerably higher in PD patients compared to controls, and one study found that frozen shoulder is the first symptom of the disease in $8 \%$ of the patients (31). Another study also showed that shoulder pain was more common in PD patients ( $80 \%$ vs. $40 \%$ ) compared to controls (32). Although it is thought that UPDRS, rigidity, and long disease duration increase shoulder complaints, shoulder complaints at the onset and before the disease are significant enough not to be ignored (33). In our study, 34 patients had shoulder pain that started before their admission (39.5\%) and the first complaint of 16 patients was shoulder pain (18.6\%). For early diagnosis, it is essential to know that this condition, which is thought to increase in frequency with immobilization due to rigidity and akinesia, may be one of the first symptoms of the disease.

Low back pain, another common complaint, was higher in PD patients than controls in various studies $(34,35)$. This has been reported more frequently at the onset of the disease, especially in women, and has been expressed to be a matter of concern (36). This condition, accompanied by more radicular pain than in the normal population, is thought to increase due to pathologies such as parkinsonism-related postural disorder, increased muscle tone, and rigidity. In our study, it was observed that 14 patients (16.3\%) had a history of low back pain and that they were treated with different diagnoses. Consistent with the literature, the frequency of low back pain is higher in female patients (36).

It has been shown that the frequency of cramp-like pain increases in Parkinson's patients $(23,37)$. In our study, it was observed that eight of the patients had cramp-like pain in the arms and legs at the onset of the disease. It shows that cramp-like pain, which may be associated with rigidity, akinesia, motor off periods, and dystonia, can be seen in the early period, and other signs and symptoms of the disease should be carefully screened.
As can be seen, PD may initially manifest itself through pain and this may lead the clinician to misdiagnosis and mistreatment (38). The use of standardized diagnostic criteria, such as the UK Brain Bank Criteria with a diagnostic specificity of $98.6 \%$ and a sensitivity of $91.1 \%$, may increase the accuracy of clinical diagnosis. However, clinicopathological studies have shown that the rate of misdiagnosis can be up to $24 \%$, even in patients examined by a movement disorders specialist $(7,39,40)$. For this reason, when symptoms start with pain and other non-motor symptoms, these patients can be evaluated by physicians of different specialties, and therefore, delays in diagnosis can be experienced. In our study, it is noteworthy that the first complaints of the patients started at the time that they applied to a physician which was $10.1 \pm 5.22$ years previous to the date of our study, but the date of diagnosis and start of treatment occurred $8.56 \pm 4.87$ years before the date of this study. The first admission of $61 \%$ of the patients was to specialties other than neurology, and only $27 \%$ were referred to neurology by another specialty because their complaints increased and treatment response was poor, and the remaining patients applied of their own initiative. In addition, the diagnosis of akinetic-rigid patients was delayed more than that of tremor dominant patients $(p<0.001)$, which suggested that akinesia, as a PD symptom, was less easily recognized both by physicians and the public than tremor symptoms. For this reason, increasing the training of related specialties other than neurology on PD and increasing public awareness about the disease are essential for early diagnosis and treatment.

One of the limitations of this study is the inability to apply pain scales and parkinsonism scales to newly diagnosed individuals at the time of admission due to its retrospective nature. Further studies will be more beneficial if planned in this way. In addition, osteoporosis, primarily due to immobility and vitamin $D$ deficiency due to patients not often being outside, could not be investigated as a cause of pain. Depression and anxiety, which are known to increase pain perception, could not be evaluated with objective scales since it is a retrospective study. Another limitation of the study is the absence of a control group. Without a control group a clear conclusion could not be reached regarding the frequency of pain in people with PD compared with other members of the population. Finally, the female to male ratio is greater in our study compared to that in the general population. This might have an effect on the results.

\section{CONCLUSION}

Patients with PD experience pain with considerable frequency at the beginning as well as during the course of the illness and this may indicate that the prodromal phase comes before the motor period. However, the di- 
agnosis may be overlooked in patients with obscure findings, and thus the patient's access to treatment might be delayed. For this reason, providing more detailed training on PD to non-Neurology specialties such as Physical Therapy and Rehabilitation, Orthopedics, Internal Medicine, and Neurosurgery will facilitate the patient's access to the correct diagnosis and treatment and increase their QoL. In addition, educating the public on PD will lead to correct admissions. Early diagnosis is also essential in prolonging the early phase of the disease and preventing motor findings when disease-modifying treatments are available.

Informed Consent: Written consent was obtained from the participants.

Ethics Committee Approval: This study was approved by the Istanbul Faculty of Medicine Ethics Committee. (Date: 22.02.2021, No: 94690).

Peer Review: Externally peer-reviewed.

Author Contributions: Conception/Design of Study- B.S., N.D.Ç., B. B., S. Ö., H.A.H.; Data Acquisition- I.D.K., B.S., N.D.Ç., B. B., S. Ö., H.A.H.; Data Analysis/Interpretation- B.S., N.D.Ç.; Drafting Manuscript- B.S., N.D.Ç.; Critical Revision of Manuscript- B.B., S.Ö., H.A.H.; Approval and Accountability- B.S., N.D.Ç., B.B., S.Ö., H.A.H.

Conflict of Interest: Authors declared no conflict of interest

Financial Disclosure: Authors declared no financial support.

\section{REFERENCES}

1. Chaudhuri KR, Schrag A, Weintraub D, Rizos A, RodriguezBlazquez C, Mamikonyan E, et al. The movement disorder society nonmotor rating scale: Initial validation study. Mov Disord 2020;35(1):116-33. [CrossRef]

2. Rodriguez-Blazquez C, Schrag A, Rizos A, Chaudhuri KR, Martinez-Martin P, Weintraub D. Prevalence of non-motor symptoms and non-motor fluctuations in Parkinson's disease using the MDS-NMS. Mov Disord Clin Pract 2021;8(2):231-9. [CrossRef]

3. DeMaagd G, Philip A. Parkinson's disease and its management: part 1: disease entity, risk factors, pathophysiology, clinical presentation, and diagnosis. P T 2015;40(8):504-32.

4. Dotchin CL, Paddick SM, Longdon AR, Kisoli A, Gray WK, Dewhurst $F$, et al. A comparison of caregiver burden in older persons and persons with Parkinson's disease or dementia in sub-Saharan Africa. Int Psychogeriatr 2014;26(4):687-92. [CrossRef]

5. Jankovic J, McDermott M, Carter J, Gauthier S, Goetz C, Golbe $L$, et al. Variable expression of Parkinson's disease: a base-line analysis of the DATATOP cohort. The Parkinson Study Group. Neurology 1990;40(10):1529-34. [CrossRef]

6. Schrag A, Ben-Shlomo Y, Quinn N. How valid is the clinical diagnosis of Parkinson's disease in the community? J Neurol Neurosurg Psychiatry 2002;73(5):529-34. [CrossRef]
7. Hughes AJ, Daniel SE, Kilford L, Lees AJ. Accuracy of clinical diagnosis of idiopathic Parkinson's disease: a clinico-pathological study of 100 cases. J Neurol Neurosurg Psychiatry 1992;55(3):181-4. [CrossRef]

8. Ford B. Pain in Parkinson's disease. Mov Disord 2010;25 (Suppl 1):S98-103. [CrossRef]

9. Postuma RB, Berg D, Stern M, Poewe W, Olanow CW, Oertel $W$, et al. MDS clinical diagnostic criteria for Parkinson's disease. Mov Disord 2015;30(12):1591-601. [CrossRef]

10. Postuma RB, Berg D. Advances in markers of prodromal Parkinson disease. Nat Rev Neurol 2016;12(11):622-34. [CrossRef]

11. Kalia LV, Lang AE. Parkinson's disease. Lancet 2015;386(9996):896-912. [CrossRef]

12. Berg D, Postuma RB, Adler CH, Bloem BR, Chan P, Dubois $B$, et al. MDS research criteria for prodromal Parkinson's disease. Mov Disord 2015;30(12):1600-11. [CrossRef]

13. Pont-Sunyer C, Hotter A, Gaig C, Seppi K, Compta Y, Katzenschlager $\mathrm{R}$, et al. The onset of nonmotor symptoms in Parkinson's disease (the ONSET PD study). Mov Disord 2015;30(2):229-37. [CrossRef]

14. O'Sullivan SS, Williams DR, Gallagher DA, Massey LA, Silveira-Moriyama L, Lees AJ. Nonmotor symptoms as presenting complaints in Parkinson's disease: a clinicopathological study. Mov Disord 2008;23(1):101-6. [CrossRef]

15. Hawkes CH, Del Tredici K, Braak H. A timeline for Parkinson's disease. Parkinsonism Relat Disord 2010;16(2):79-84. [CrossRef]

16. Barone P, Antonini A, Colosimo C, Marconi R, Morgante $\mathrm{L}$, Avarello TP, et al. The PRIAMO study: A multicenter assessment of nonmotor symptoms and their impact on quality of life in Parkinson's disease. Mov Disord 2009;24(11):1641-9. [CrossRef]

17. Buhmann C, Wrobel N, Grashorn W, Fruendt O, Wesemann K, Diedrich S, et al. Pain in Parkinson disease: a crosssectional survey of its prevalence, specifics, and therapy. J Neurol 2017;264(4):758-69. [CrossRef]

18. Tolosa E, Compta Y, Gaig C. The premotor phase of Parkinson's disease. Parkinsonism Relat Disord 2007;13 (Suppl):S2-7. [CrossRef]

19. Valkovic P, Minar M, Singliarova H, Harsany J, Hanakova M, Martinkova J, et al. Pain in Parkinson's disease: a cross-sectional study of its prevalence, types, and relationship to depression and quality of life. PLoS One 2015; 10(8):e0136541. [CrossRef]

20. Lee MA, Walker RW, Hildreth TJ, Prentice WM. A survey of pain in idiopathic Parkinson's disease. J Pain Symptom Manage 2006;32(5):462-9. [CrossRef]

21. Negre-Pages $L$, Regragui $W$, Bouhassira D, Grandjean $H$, Rascol O, DoPaMi PSG. Chronic pain in Parkinson's disease: the cross-sectional French DoPaMiP survey. Mov Disord 2008;23(10):1361-9. [CrossRef]

22. Ford B. Pain in Parkinson's disease. Clin Neurosci 1998;5(2):63-72.

23. Defazio G, Berardelli A, Fabbrini G, Martino D, Fincati E, Fiaschi $A$, et al. Pain as a nonmotor symptom of Parkinson disease: evidence from a case-control study. Arch Neurol 2008;65(9):1191-4. [CrossRef]

24. Beiske AG, Loge JH, Ronningen A, Svensson E. Pain in Parkinson's disease: Prevalence and characteristics. Pain 
2009;141(1-2):173-7. [CrossRef]

25. Silverdale MA, Kobylecki C, Kass-lliyya L, Martinez-Martin P, Lawton M, Cotterill S, et al. A detailed clinical study of pain in 1957 participants with early/moderate Parkinson's disease. Parkinsonism Relat Disord 2018;56:27-32. [CrossRef]

26. Tueth LE, Duncan RP. Musculoskeletal pain in Parkinson disease: a narrative review. Neurodegener Dis Manag 2021;11(5):373-85. [CrossRef]

27. Bonenfant $\mathrm{D}$, Rompre $\mathrm{PH}$, Rei N, Jodoin N, Soland $\mathrm{VL}$, Rey $\mathrm{V}$, et al. Characterization of Burning Mouth syndrome in patients with Parkinson's disease. J Oral Facial Pain Headache 2016;30(4):318-22. [CrossRef]

28. Blanchet PJ, Brefel-Courbon C. Chronic pain and pain processing in Parkinson's disease. Prog Neuropsychopharmacol Biol Psychiatry 2018;87(Pt B):200-6. [CrossRef]

29. Hanagasi HA, Akat S, Gurvit H, Yazici J, Emre M. Pain is common in Parkinson's disease. Clin Neurol Neurosurg 2011;113(1):11-3. [CrossRef]

30. Kim YE, Lee WW, Yun JY, Yang HJ, Kim HJ, Jeon BS. Musculoskeletal problems in Parkinson's disease: neglected issues. Parkinsonism Relat Disord 2013;19(7):6669. [CrossRef]

31. Riley $D$, Lang AE, Blair RD, Birnbaum A, Reid B. Frozen shoulder and other shoulder disturbances in Parkinson's disease. J Neurol Neurosurg Psychiatry 1989;52(1):63-6. [CrossRef]

32. Madden MB, Hall DA. Shoulder pain in Parkinson's disease: a case-control study. Mov Disord 2010;25(8):1105-6. [CrossRef]
33. Yucel A, Kusbeci OY. Magnetic resonance imaging findings of shoulders in Parkinson's disease. Mov Disord 2010;25(15):2524-30. [CrossRef]

34. Broetz D, Eichner M, Gasser T, Weller M, Steinbach JP. Radicular and nonradicular back pain in Parkinson's disease: a controlled study. Mov Disord 2007;22(6):853-6. [CrossRef]

35. Etchepare F, Rozenberg S, Mirault T, Bonnet AM, Lecorre C, Agid Y, et al. Back problems in Parkinson's disease: an underestimated problem. Joint Bone Spine 2006;73(3):298302. [CrossRef]

36. Scott B, Borgman A, Engler H, Johnels B, Aquilonius SM. Gender differences in Parkinson's disease symptom profile. Acta Neurol Scand 2000;102(1):37-43. [CrossRef]

37. Rugbjerg K, Friis S, Jorgensen TL, Ritz B, Korbo L, Olsen JH. Risk for Parkinson's disease among patients with osteoarthritis: a Danish cohort study. Mov Disord 2010;25(14):2355-60. [CrossRef]

38. Stamey W, Davidson A, Jankovic J. Shoulder pain: a presenting symptom of Parkinson disease. J Clin Rheumatol 2008;14(4):253-4. [CrossRef]

39. Hughes AJ, Daniel SE, Lees AJ. Improved accuracy of clinical diagnosis of Lewy body Parkinson's disease. Neurology 2001;57(8):1497-9. [CrossRef]

40. Hughes AJ, Daniel SE, Ben-Shlomo Y, Lees AJ. The accuracy of diagnosis of parkinsonian syndromes in a specialist movement disorder service. Brain 2002;125(Pt 4):861-70. [CrossRef] 